\title{
Communicating Scientific Choices in a Multilingual EU: The Position of "Third Parties" in EU Agencies’ Technical Assessments
}

\author{
Alessia MONICA* (1)
}

\begin{abstract}
Frequently, decisions related to health protection are taken directly on the basis of scientific assessment and they are not clearly understood, as is highlighted in the Xylella example. Therefore, this article suggests that coherent processing of information in risk assessment may allow also a "third party" (who has not already expressed a specific interest in the procedure) to participate. In order to truly grasp the EU administration, an accountable way of communicating is helpful. Therefore, communication around the democratic process might be based on EU administrative principles and rules supporting a composite administrative system: it must not neglect the implications of compliance with the multilingual principle and its consequences for EU law, which would also lead to greater trust in risk assessment.
\end{abstract}

\section{INTRODUCTION}

The activity of risk assessment and the communication of its results has always had different impacts for different target audiences, including the general public. Most legal scholarship has mainly focused on the relationship between the addressee of administrative action, the decision or the responses to requests and the administration: this often leads to situations where "third parties' rights to information and involvement" are being ignored. ${ }^{1}$ In this way, for example, the interest of a "third party" such as the European Food Safety Authority (EFSA) is not directly involved in technical agency opinion development, but is indirectly touched or influenced by the consequences. This article aims to link the emerging interests of "third parties" in a multilingual EU administration when supported by technical experts.

As a preliminary remark, one must taken into account whether the communication of an assessment, particularly an assessment containing uncertainty, should be tailored according to a frame of principles and methods that takes due account of the aspirations of the involvement of subjects, such as "third parties" (Section IV).

\footnotetext{
* University of Pavia; email: alessia.monica@unipv.it.

1 J Ziller, "Conclusioni”" in N Bassi and J Ziller (eds), La formazione procedimentale della conoscenza scientifica ufficiale: il caso dell'Agenzia europea per la sicurezza alimentare (EFSA) (Turin, Giappichelli 2017) p 160.
} 
Secondly, it is well known that science is based on certainty that might not be accurate and could be improved upon in the future ${ }^{2}$ : its task is to contribute to risk analysis and to establish whether there might be a potential risk or danger involved. ${ }^{3}$ Moreover, making the communication of a scientific choice understandable, with due respect to the legal framework of the EU, seems to be difficult in a multilingual EU.

An example of this complexity is given by the Xylella case. ${ }^{4}$ Technical assessments carried out by EFSA, which have supported the EU Commission measures enforcing the eradication the Xylella bacterium, have triggered a heated ongoing debate - above all in Italy - because many "interested parties" or "future interested third parties" would be impacted by these measures. Thus, having explained the essential facts concerning the Xylella case (Section II), I aim to underline the seminal point in the reasoning of the EU Court, which declared the validity of Article 6 of the Implementing Decision 789/2015 of the EU Commission.

The basic idea that emerges in reviewing all of the steps preceding the Xylella matter is that the development of technical assessment is not always deeply understood. Hence, this makes it difficult for subjects who are not "formally" parties to trust risk assessment. This tension leads me to wonder whether a better-understood process of risk assessment would be a more accountable approach (Section V). For this reason, in my conclusion (Section VI), I also suggest that "third parties" should be informed about and involved in technical assessment, which would also help us to avoid problems of non-corresponding document and act translations. In addition, as far as possible, respecting the EU multilingual principle might be a tool for "renewed" risk communication.

\section{The facts IN QUeSTION IN THE XyLELLa CASE}

Since 2013, the Xylella bacterium has infected several olive trees in southern Apulia (the name given to the Italian strain is CoDiRO - "olive quick decline syndrome"). Nonetheless, the issue was of interest to EU law because Xylella had also affected groves in other parts of the EU, such as France and Spain. Based on Directive $29 / 2000^{5}$ regarding protective measures against the introduction into the Community of harmful organisms to plants or plant products and against their spread within the Community (in particular, Articles 16 and 19), the EU Commission is allowed to take Implementing Decision (Article 291 Treaty on the Functioning of the European Union (TFEU)). For this reason, at first, Implementing Decision 87/20146 was

\footnotetext{
2 S Balckburn, What Do We Really Know? The Big Questions of Philosophy (London, Quercus 2016) pp 41-52.

3 M Silano and V Silano, "The European Union Food Safety System" (2013) 12 Nutrafoods 103; A König et al, "The Safe Foods Framework for Improved Risk Analysis of Foods" (2010) 21 Food Control 1566.

4 Accademia dei Lincei, Rapporto Xylella, 23 June 2016 <www.lincei.it/it/content/rapporto-xylella>.

5 Council Directive (EC) 29/2000 on protective measures against the introduction into the Community of organisms harmful to plants or plant products and against their spread within the Community, [2000] OJ L 169; now amended by Regulation (EC) 2031/2016 on protective measures against pests of plants, [2016] OJ L 317.

6 Commission Implementing Decision (EU) 2014/87 as regards measures to prevent the spread within the Union of Xylella fastidiosa (Well and Raju), [2014] OJ L 45.
} 
adopted. Following the publication of EFSA's Scientific Opinion on 6 January 2015, ${ }^{7}$ it has been replaced by Implementing Decision $789 / 2015,{ }^{8}$ which included the identification and evaluation of the reduced risk option. Expressly, this new Implementing Decision refers to the Scientific Opinion in recital no. 2 and to its assessments as the premise for the review of the previous Implementing Decision 87/2014. ${ }^{9}$ The provision of Article 6 is the immediate removal of host plants within a radius of $100 \mathrm{~m}$ around: plants that have been tested and found to be infected with the specified organism, regardless of their health status; plants known to be infected with the specified organism; and plants showing symptoms indicating possible infection with that organism or suspected of being infected with that organism. Moreover, prior to the removal, the Member State shall carry out appropriate phytosanitary treatments against the vectors of the specified organism and plants that may host those vectors. Treatment may include removal of plants. Again, it is the Member State that has the duty to enforce the measures provided by the Implementing Decision itself.

In a new Scientific Opinion dated 20 April 2016, EFSA concluded that the experimental treatments in Apulian olive orchards infected with strain CoDiRO could potentially have positive effects, but would not eliminate the pathogen Xylella fastidiosa from the treated infected plants. ${ }^{10}$ In any case, even though the scientific community had the duty to fill these knowledge gaps, at the same time eradication measures had to be executed. Regarding this point, local farmers put forwards an action for the annulment of national eradication and implementation measures. Consequently, the national administrative judge proposing the preliminary ruling on the validity of Implementing Decision 789/2015 (based on Directive 29/2000) allowed for the immediate suspension of the eradication measures ${ }^{11}$ as provisional measures. The issue of the preliminary ruling related to the proportionality and the accuracy of the obligation imposed on Member States. In judgement Pesce and Others,${ }^{12}$ the Court stated that the eradication measure within $100 \mathrm{~m}$ was necessary and proportional to the objective of eradicating the disease $\mathrm{e}^{13}$ and confirmed that the vector was not the plant, as the applicants had erroneously submitted, but rather insects settling on the plants

\footnotetext{
7 EFSA, "Scientific Opinion on the Risk to Plant Health Posed by Xylella fastidiosa in the EU Territory" (2015) 13 EFSA Journal 3989.

8 Commission Implementing Decision (EU) 2015/789 as regards measures to prevent the introduction and the spread within the Union of Xylella fastidiosa (Wells et al), [2015] OJ L 125.

9 This decision was anticipated by the constant and lengthy debate with other EU institutions and the Member State. The Commission, for instance, was asked for an oral reply to the question by the Committee on Agriculture and Rural Development: <www.europarl.europa.eu/sides/getDoc.do?pubRef=-//EP//TEXT+OQ+O-2015-000038+ $0+\mathrm{DOC}+\mathrm{XML}+\mathrm{V} 0 / / \mathrm{EN}>$. Consequently, the EU Parliament reaffirmed its position on the problem with a Resolution on 20 May 2015 on the outbreak of Xylella fastidiosa affecting olive trees - 2015/2652(RSP): <www.europarl.europa. eu/sides/getDoc.do?pubRef=-//EP//TEXT+TA+P8-TA-2015-0209+0+DOC+XML+V0//EN>.

10 EFSA, "Treatment Solutions to Cure Xylella fastidiosa Diseased Plants" (2016) 14 EFSA Journal 1.

11 TAR Lazio, sez. I, 22 January 2016, n. $780<$ www.giustizia-amministrativa.it $>$ for the preliminary ruling Pesce and Others (infra, note 12), which had also established provisional measures such as stopping eradication measures.

12 Case C-78/16, Pesce and Others, ECLI:EU:C:2016:428. A Monica, "Segnalazione-Pesce e altri C-78/16" (2016) 6 Rivista Italiana di Diritto Pubblico Comunitario 1640; M Postiglione, "La Corte di Giustizia si pronuncia sulle misure adottate dalla Commissione per impedire l'introduzione e la diffusione nell'Unione della Xylella fastidiosa" (2016) $<$ Eurojus.it> (last accessed 22 June 2016); S Rosét, "Protection sanitaire des vegéteaux et principe de précaution" (2016) 8-9 Europe 36.

13 Pesce and Others, supra, note 12, paras 66 and 68.
} 
may have acted as vectors of the infection. ${ }^{14}$ The causal link between the bacterium and the rapid desiccation of the olive trees was not certain, but there was evidently a significant correlation between the Xylella bacterium and the olive tree disease, as highlighted in EFSA's opinion. ${ }^{15}$

Due to this fact, as far as Italian farmers are concerned, I could argue that the scientific evidence has not been completely trusted, with the consequence being that the eradication measures have not been perceived as necessary for food safety. In this sense, there might be a "problem of communication," which has also had implications from a legal perspective. ${ }^{16}$ To begin with, according to the Italian administrative judge and public opinion, the olive farmers, consumers and local authorities in the south of Italy seem not to be aware of upon what basis the scientific opinion of EFSA, sustaining the decision of the Commission, has been provided. ${ }^{17}$ The decision of the Commission was presented or interpreted in a purely discretionary way, without the purpose - in its own motivation - of any possible alternative to the radical measures planned by Article 6 of Implementing Decision 789/2015. ${ }^{18}$ In fact, it is each Member State that must immediately notify the Commission and other Member States of the presence in its territory of any harmful or potentially harmful organisms, and it must take all necessary measures to eradicate it. If that is impossible, it has to inhibit the spread of the harmful organisms concerned. Each Member State also has the duty to inform the Commission and the other Member States of the measures taken. However, the Commission must examine the situation as quickly as possible within the Standing Committee on Plants, Animals, Food and Feed (PAAF), ${ }^{19}$ according to Article 16, Paragraph 3 of Directive 29/2000, which is composed of representatives of all of the Member States and presided over by a representative of the Commission. "The Committee shall deliver its opinion on the draft within two days. The opinion shall be delivered by the majority as specified in Article 205(2) of the TCE [now Article 238 TFEU] in the case of decisions in which the Council is required to adopt a proposal from the Commission". ${ }^{20}$ In any case, the Commission, in accordance with the precautionary principle, ${ }^{21}$ has significant discretionary power, including the power to

14 EFSA, "Scientific Opinion", supra, note 6, 109-111; Case C-78/16, Pesce and Others, supra, note 12, para 35.

15 Pesce and Others, supra, note 12, para 59; Opinion of AG Bot, ECLI:EU:C:2016:340, para 116; F Munari, "Il ruolo della scienza nella giurisprudenza della Corte di giustizia in materia di tutela della salute e dell'ambiente" (2017) 1 Il Diritto dell'Unione Europea 131.

16 Inter alia, IA Irwin and B Wynne (eds), Misunderstanding Science? The Public Reconstruction of Science and Technology (Cambridge, Cambridge University Press 1996).

17 TAR Lazio, sez. I, n. 780, supra, note 11, para 3.2.4.

18 ibid, para 3.3. "The principle of proportionality would therefore have required the Commission to examine all of the possible alternative measures and subsequently to choose, among these, the right one to achieve the goal with the least sacrifice, since fundamental values (such as health, the environment and the landscape) are at stake. Implementing Decision 789/2015, however, does not propose, in its own motivation, any alternative with respect to the radical measure prepared by it in Article 6, Paragraph 2, lett. a" (my translation); G Strona et al, "Network Analysis Reveals Why Xylella fastidiosa Will Persist in Europe" (2017) 7 Scientific Reports 71.

$19<$ https://ec.europa.eu/food/plant/standing_committees/sc_plant_health_en > .

20 Council Directive (EC) 29/2000, supra, note 5, Art 19.

21 Communication from the Commission on the precautionary principle, COM [2000] 001 final; D Vogel, The Politics of Precaution: Regulating Health, Safety, and Environmental Risks in Europe and the United States, (Princeton, NJ, Princeton University Press 2012) p 278. Inter alia, A Alemanno, "Le principe de précaution en droit communautaire: stratégie de gestion des risques ou risque d'atteinte au marché intérieur?" (2001) 2 Revue du droit de l'Union Européenne 917. 
decide whether measures taken by the Member States should be rescinded or amended. ${ }^{22}$ On closer examination of Implementing Decision 789, it is clear how, for both the sampling of plants and for other pest eradication measures (Article 6, Paragraphs 3 and 10), Member States shall refer to the International Standards for Phytosanitary Measures (ISPMs) ${ }^{23}$ of Food and Agriculture Organization of the United Nations (FAO). The subscription of international standards was not recalled in the debate, but it is quite common in EU rulemaking. ${ }^{24}$ Yet, regarding the food safety sector, national regulations are often based both on safety standards from EU authorities and on international food standards, such as the Codex Alimentarius, established by the FAO in 1963 in collaboration with the World Health Organization (WHO). ${ }^{25}$ Furthermore, Article 13 of Regulation 178/2002 not only states that the Community and Member States shall contribute to the development of new international standards, but that they shall also "promote consistency between international technical standards and food law while ensuring that the high level of protection adopted in the Community is not reduced". Thus, in the case analysed in this article, it could be considered that a discretionary Commission decision setting the eradication measures became a topic of a wider polemic. On the other hand, many actors were involved besides EFSA and the Commission, clearly demonstrating that the implementation of EU law is articulated at a plurality of levels. ${ }^{26}$ Not only did the Member States sign the ISPMs, but they also took part in the PAAF, and they have conferred implementing powers on the Commission according to the principle of sincere cooperation and Article 291 TFEU.

Notwithstanding the transparent selection procedure of scientific experts that EFSA has to ensure, ${ }^{27}$ as well as the effective contacts the agency develops with consumers and interested parties, ${ }^{28}$ it may seem that EFSA's support of risk management based on the assessment and independent evaluation of risks is self-referential. It is true that the Commission, in regard to these scientific data, was entitled to take the view that the obligation to immediately remove all host plants located near infected plants was

\footnotetext{
22 Council Directive (EC) 29/2000, supra, note 5, Art 16, para 3.

23 FAO, International Standards for Phytosanitary Measures <www.ippc.int/en/core-activities/standards-setting/ ispms $>$.

24 J Mendes, "EU Law and Global Regulatory Regimes: Hollowing Out Procedural Standards?" (2012) 10 International Journal of Constitutional Law 988, 1020: "International organizations and global regulatory bodies have sought to submit their actions to self-created standards that, at least (possibly at best, in some cases), create the appearance that they do not pursue their own interests irrespective of the public interests they proclaim (e.g., food safety, environmental protection, market or trade regulation)"; see also J Mendes, "Administrative law beyond the state: participation at the intersection of legal systems" in E Chiti and BG Mattarella, Global Administrative Law and EU Administrative Law (Berlin, Springer 2011) p 111.

25 BG Mattarella, "The Influence of European and Global Administrative Law" in E Chiti and BG Mattarella, Global Administrative Law and EU Administrative Law (Berlin, Springer 2011) p 68. The Codex Alimentarius was established by a joint intergovernmental commission of FAO and WHO; see M Livermore, "Authority and Legitimacy in Global Governance: Deliberation, Institutional Differentiation and the Codex Alimentarius" (2006) 81 New York University Law Review 766.

26 A Volpato, "Controlling the Invisible: Accountability Issues in the Exercise of Implementing Powers by EU Agencies and in Harmonised Standardisation" (2019) 12 Review of European Administrative Law 75.

27 See, above all, Art 28 of Regulation 178/2002 and the EFSA website: <www.efsa.europa.eu/en/about/ corporatedocs? accordionSection $=2>$.

28 Arts 9 and 42 Regulation 178/2002.
} 
an appropriate and necessary measure for preventing the spread of the bacterium Xylella. ${ }^{29}$ In any case, the seminal objection advanced by environmental groups, ${ }^{30}$ local Italian authorities and the applicants in the Xylella case was for the possibility of alternative measures to be evaluated. For example, a non-governmental organisation (NGO) claimed that Xylella is not the cause of olive tree decline in Lecce Province in southern Italy, but rather it is due to an endogenous element present in the trees that is not active or aggressive unless a series of fungi infect the plants and create the right conditions for the development of Xylella. ${ }^{31}$ This misrepresentation of facts and of roles played discloses the problem of communication, and in this case the Commission was supposed to be the scapegoat. ${ }^{32}$ Maybe this is a consequence of the lack of national representatives in the management board involved in the EFSA decision-making process through the advisory forum, or this could also be an effect of populist rhetoric that makes public opinion reluctant to accept conclusions based on purely scientific elements. ${ }^{33}$ In any case, different understandings of the political choices may be caused by different approaches towards the uncertainty inherent in the decision-making process, involving "different perspectives on the relevance to be given to public opinion". ${ }^{34}$ As the genetically modified organism (GMO) case reminds us, there are many examples of doubt being cast on the integrity of EU scientific assessments. For instance, every GMO product needs prior authorisation at the EU level, including a scientific assessment by EFSA, for both its cultivation and sale. In addition, many of EFSA's positions have already been challenged in the past, especially where EFSA assessments have had huge impacts on agriculture and trade associations, ${ }^{35}$ as indeed the Xylella case and the strong public objections have shown. ${ }^{36}$ The Xylella bacterium, which has not yet been eradicated, can be hosted in a very broad range of plants: this fact means that new "stakeholders", such as citrus farmers, would be impacted by the implementation of eradication measures and their consequences. ${ }^{37}$

\footnotetext{
29 Pesce and Others, supra, note 12, para 73.

30 Accademia dei Lincei, Rapporto Xylella, supra, note 4, pp 7 and 55.

31 EFSA, "Response to Scientific and Technical Information Provided by an NGO on Xylella fastidiosa" (2015) 13 EFSA Journal 4082.

32 Perhaps this is due to the lack of institutionalised contact between Member State politicians and national authorities involved in the EFSA decision-making process through the advisory forum, but not the management board. MLP Groenleer, "Agency Autonomy Actually: Managerial Strategies, Legitimacy, and the Early Development of the European Union's Agencies for Drug and Food Safety Regulation” (2014) 17 International Public Management Journal 255, 283, is of this opinion.

33 ibid, "And even if science were perfectly objective, politicians and the general public are not always willing to accept conclusions that only take into account purely scientific factors", p 280.

34 E Chiti, "Is EU Administrative Law Failing in Some of Its Crucial Tasks?" (2017) 5 European Law Journal 593.

35 M Morvillo, "The General Court Orders Disclosure of Glyphosate-Related Scientific Studies: Tweedale, Hautala, and the Concept of Environmental Information in the Context of Plant Protection Products" (2019) 10 European Journal of Risk Regulation 419.

36 Accademia dei Lincei, Rapporto Xylella, supra, note 4, p 28.

37 See the EFSA press release of 26 November 2016: <www.efsa.europa.eu/en/press/news/131126>; Commission Implementing (EU) 2018/927 of 27 June 2018 amending Implementing Decision (EU) 2015/789 as regards measures to prevent the introduction into and the spread within the Union of Xylella fastidiosa (Wells et al).
} 


\section{THE ACTORS INVOLVED IN RISK REGULATION}

As exemplified in the Pesce and Others case, the role of EFSA and other research centres seems not to be entirely clear to every possible stakeholder. In this uncertainty and lack of trust, everyone has tried to avoid the application of binding measures, opposing their personal interests against the general interests of safeguarding environmental and consumer health. Public distrust of science has led to conspiracy theories that have hampered control efforts. ${ }^{38}$ In addition, pending the Court's ruling, the Italian authorities delayed giving complete execution of the Implementing Decision as a precautionary measure taken by the Italian administrative courts. ${ }^{39}$ For this reason, an infringement procedure (pursuant to Article 258 TFEU) has been opened, and the Court $^{40}$ has recently declared that Italy had failed to fulfil two of its obligations under Commission Decision 789/2015 (as amended by Decision 764/2016). Furthermore, the Italian authorities, answering to a formal notice of the Commission, put the focus on public distrust of science ${ }^{41}$ and upheld that, as a result of pending reference for a preliminary ruling on C-78/16 and C-79/16, the compulsory felling of trees had drastically slowed down. In this way, the execution of part of Implementing Decision $789 / 2015$ had become legally impossible. ${ }^{42}$ With reference to this argument, it should be noted that the Court made a point of reminding everyone that a Member State may not rely on situations in its domestic legal system to justify its failure to comply with obligations and time limits resulting from EU law. ${ }^{43}$

All things considered, not only must there be sincere cooperation between the Commission and Member States, but also between the agencies providing seminal technical assistance in case of emergencies or during the risk evaluation process. ${ }^{44}$ This is particularly important regarding those agencies providing technical opinions (not only of the formal kind). EFSA, for example, as a "results-orientated functional administration", ${ }^{45}$ takes part in decision-making and coordinating networks and groups of experts to find an acceptable compromise among the opinions, reports and scientific research that has been carried out. It plays as "in-betweener" role that not only assists EU institutions, but also Member States (and their administrations), providing scientific advice for both legislation and its implementation. ${ }^{46}$

38 RPP Almeida, “Can Apulia's Olive Trees Be Saved?" (2017) 353 Science 347; see also infra, note 91.

39 TAR Lazio, sez. I, n. 780, supra, note 11.

40 Case C-443/18, Commission v. Italia (Xylella fastidiosa bacterium), [2019] ECLI:EU:C:2019:676, para 90.

41 ibid, para 31.

42 ibid, para 16.

43 ibid, para 45. It should also be specified that the failure of Italy to fulfil obligations does not concern the eradication measures, the proportionality of which is the subject of the judgement Pesce and Others, but specifically refers to the failing to ensure a containment area near the province of Lecce, provided by Art 7 of the Implementing Decision. In fact, the Commission has not demonstrated that the Italian Republic has repeatedly infringed the specific obligations laid down in Art 6 (ibid, para 81). A Monica, "Segnalazione - Commissione c. Repubblica italiana C-443/18" (2019) 3-4 Rivista Italiana di Diritto Pubblico Comunitario 557.

44 E Chiti, "European Agencies' Rulemaking: Powers, Procedures and Assessment" (2013) 19 European Law Journal 96.

45 Translated by the author from the Italian, see MP Chiti, "La legittimazione per risultati dell'Unione europea quale "comunità di diritto amministrativo"” (2016) 2 Rivista Italiana di Diritto Pubblico Comunitario 397.

46 Conference, EU Agencies as "Inbetweeners"? The Relationship between EU Agencies and Member States, Maastricht University, 4-5 December 2019. 
Thus, to achieve coherent processing of information that allows science to be deeply trusted, there is a need to make scientific techniques more "understandable" with the support of procedural guarantees. This aims to counterbalance the independence of epistemic knowledge with political and representative powers, as the speed of political decision-making is faster than the speed of scientific consensus formation, which also has to struggle against general ignorance fuelled by social media and social movements. ${ }^{47}$ In this manner, the hope is to overcome the lack of trust and of consequent accountability of composite procedures such as "risk regulation". ${ }^{48}$ In this case, not only EU law or national law were included, but also references to the international food standards of the FAO and international law. All of these parts of the "cluster" of both risk assessment and risk management need to be known understood. It is true that EU administrative law is a mix of EU and national principles, rules and practices, subject to the influence of international law. ${ }^{49}$ In my view, this is an important turning point that gives even more emphasis to the problem of communication. Thus, it is questionable as to whether all of those involved in the production of olive oil are really aware of the compliance to international standards, particularly, in this case, of the eradication measures that are binding for Member States.

\section{THE INTEREST OF A "THIRD PARTY"}

Having reviewed the roles of all institutional actors involved, the common thread of this article is the role of "third parties" (natural or legal persons), and in this sense their possible involvement in risk assessment should be clarified.

With reference to Xylella, only EFSA and the Commission (in part as Member States) are formally "parties" to the procedure that leads to the final EU Commission's decision to implement measures, whereas other "third parties", structured or not, may be concerned by these measures, such as local olive farmers, trade associations and consumers. They are also impacted by all intermediary decisions and preparatory acts, which do not have directly legally binding effects. For example, the farmers were the "third party" affected by the decisional process who tried to stop the consequences of the decision by appealing to the national administrative courts because the eradication measures were damaging their crops. ${ }^{50}$

Clearly, the role of "third parties" is strictly related to agency regulatory capacity, and above all, judicial review is only possible for "binding decisions", not for "non-binding advice". In this sense, with the aim of fostering trust in risk assessment procedures based on scientific evidence, we should try to explain the possible connection between the interests of "third parties" and, above all, their rights to information

\footnotetext{
47 C Colella, R Carradore and A Cerroni, "Problem Setting and Problem Solving in the Case of Olive Quick Decline Syndrome in Apulia, Italy: A Sociological Approach” (2019) 109 Phytopathology 187.

48 This procedure would follow the traditional pattern of a two-level system, distinguishing only EU and national levels: H Hoffmann, "Composite Decision Making Procedures in EU Administrative Law" in Legal Challenges in EU Administrative Law (Cheltenham, Elgar 2009) pp 136-67.

49 E Chiti, Is EU Administrative Law Failing in Some of Its Crucial Tasks?, supra, note 34, p 581. Chiti affirms that the different understandings of the room left to political choice are caused by "different attitudes towards the uncertainty inherent the decision-making process", p 593.

50 TAR Lazio, sez. I, n. 780, supra, note 11.
} 
about risk assessment. Furthermore, how are these connections relevant in the processes of accountability and, in particular, for those activities that aim to balance short-term interests with the protection of health? When considering the role of the communication of activities, it is important to delineate the boundaries of those "third parties" who have a genuine interest in the procedure and whether (or not) the activities of the agencies are the final product of a long series of consultations and shared opinions. In addition, a further question may be whether a person who has not expressed a specific interest in a procedure should be involved and encouraged to participate or not.

For greater clarity, it is still necessary to define the role of "third parties". In conformity with rulemaking acts, the term "third party" is used in a wider sense, and it also embodies the "general public", as set out in Article 11 of the Treaty of the European Union (TEU) that "give[s] citizens and representative associations the opportunity to make known and publicly exchange their views in all areas of Union action". At the same time, "The European Commission shall carry out broad consultations with parties concerned in order to ensure that the Union's actions are coherent and transparent". In order to go beyond the borders of the "participation" - as suggested by ReNEUAL (a network focusing on EU administrative law, ${ }^{51}$ providing a series of "model rules" tailored for the adjudication) - a "party" who might be directly affected in the future could also be consulted. ${ }^{52}$

However, in the case of a single decision, a "third party" may be anyone who is directly affected by a procedure or is adversely affected and - not least - anyone who is requested to be involved in the procedure. To sum up, there may be four different types of "third party": "the addressee of a decision ${ }^{53}$; anyone who is adversely affected and who has requested to become a party to the procedure; anyone who expresses an (any legitimated) interest in the procedure; anyone who has not expressed any interest in the procedure". 54

Quoting from the recent Proposal for a Regulation of the European Parliament and of the Council for an Open, Efficient and Independent European Union Administrationof theEU Parliament, "party" means any natural or legal person whose legal position may be affected by the outcome of an administrative procedure. ${ }^{55}$ This proposal, using the concept of "administrative procedure", differs in terms of quality from "individual decision". ${ }^{56}$ It is not necessary for a person to make a request for such purposes to be considered as a party, and it could simply be a person whose legal

\footnotetext{
51 ReNEUAL working groups have developed a set of model rules from 2009 until 2014. The ReNEUAL Model Rules 2014 are designed as a draft proposal for binding legislation identifying - on the basis of comparative research - best practices regarding different specific policies of the EU in order to reinforce the general principles of EU law: <www.reneual.eu>.

52 ReNEUAL, Model Rules, Book II-II.4: <www.reneual.eu>.

53 ibid, Book III, Art III-2, Definitions.

54 J Ziller, "Protecting Third Parties to Eu Administrative Procedures: Rules in Adjudication and Institutional Design" in RL Weaver, D Fairgrieve and SI Friedland (eds.) Administrative Law, Administrative Structures and Administrative Decisionmaking: Comparative Perspectives (Durham, NC, Carolina Academic Press, 2018) pp 49-54.

55 European Parliament, Proposal for a Regulation of the European Parliament and of the Council for an Open, Efficient and Independent European Union Administration: <www.europarl.europa.eu/meetdocs/2014_2019/plmrep/ COMMITTEES/JURI/DV/2016/01-28/1081253EN.pdf>, 9 June 2016, Art 4, f.

56 J Ziller, "Conclusioni", supra, note 1, p 168.
} 
position may be affected by the results of an administrative procedure, not only one who suffers a direct prejudice. It would be interesting to compare this proposal with the term "participation" as delineated in the Olivieri T-326/99 case, where it is relegated by the strict boundaries of the "bringing proceedings". The participation of a "third party" (who is in this case an expert in the assessment procedure) "is therefore solely confined to the production of relevant information and does not extend [to the scientific assessment of further data, which is a matter for the Commission]". ${ }^{57}$ Here, the Court clearly affirms that "in [their] capacity as third party, is not entitled to participate in [...] the procedure". ${ }^{5}$

\section{The communication of risk and the interest of a "third party"}

All things considered, if there were a link between participation and the role of a "third party" in a semi-defined act or a preparatory act, such as an opinion of an agency like EFSA, it would be through the impact of this act on the party's legal position. Since the interest of a "third party" is directly affected by communication activities and communication is related overall to the legal protection of the stakeholder, communication without a purpose may be useless. ${ }^{59}$ As far as EFSA is concerned, an active engagement "in a formalized mechanism" seems to be missing, with the exception of the provision of Article 12 of Regulation 1107/2009 (which allows a period of 60 days for the submission of written comments to EFSA and where the draft assessment report is partially available to the public). ${ }^{60}$

In relation to the Xylella case, what protections are today given to farmers (the "third party" directly affected by the Implementing Decision) and to consumers (affected by the consequences on the olive oil market as an effect of the Implementing Decision)? Apart from any possible matter of compensation, which is a duty for the national judge, the participation of "new and possible" interested parties is also useful in relation to every legal accountability issue. As has already been said, it would be possible for "new individuals", not only olive farmers, but also, for example, citrus farmers, to be subject to the effects of the outcomes of eradication measures or of "containment measures". ${ }^{61}$ For this reason, an independent regulatory process that is trusted and shared by all parties involved is of paramount importance in order to strengthen EFSA's credibility and independence. Moreover, in order for the citizens to have faith in science, knowledge of scientific progress must be disseminated in a comprehensible manner so as to improve the awareness of all parties concerned. This would allow us to ensure that administrative activity could be developed as a co-administration at various levels, and it would further enhance the democratic functioning of the EU.

57 Case T-326/99, Olivieri, ECLI:EU:C:2001:506, paras 91 and 93. See also C Barnard and S Peers, European Union Law (Oxford, Oxford University Press 2014), p 642.

58 Case T-326/99, Olivieri, supra, note 57, para 94.

59 The Communication Handbook for the EU Agencies claims, "However, successful communication can only happen if communication and stakeholder relations are factored in from the outset": $<$ https://europa.eu/europeanunion/sites/europaeu/files/docs/body/2013-12-10_communication_handbook_en.pdf >, p 4.

60 N Bassi, "Introduzione" in N Bassi and J Ziller (eds), La formazione procedimentale della conoscenza scientifica ufficiale: il caso dell'Agenzia europea per la sicurezza alimentare (EFSA), supra, note 1.

61 J Ziller, "Conclusioni”, supra, note 1. 


\section{The “THIRD PARTY” EMERGING INTEREST IN A MULTILINGUAL EU}

To the partial lack of some of possible "third parties" in the drawing up of a decision or internal review ${ }^{62}$ must be added the lack of a duty for agencies to translate their publications into every official language of the EU. It may seem that these are two different and unrelated issues, but they both may be linked properly through the argument of this article: namely, highlighting the obstacles to constant "third party" dialogue with European institutions and administrations. In this way, it is worth linking the "interest of a third party" to the multilingual issues in such a specific context as scientific assessment.

As a premise, it is to be noted that every official language of the EU has the same legal status and equal value: according to Regulation $1 / 58,{ }^{63}$ there are now 24 official languages recognised by EU law. As a consequence of this, due to the direct effect of regulation and in order to ensure its uniform application, all legal acts of EU law must be translated into all 24 official languages. ${ }^{64}$ The right of citizens to communicate in one of the official EU languages with EU institutions is also stated in the Treaties: Article 24.4 TFEU "gives a Treaty basis to the rights of citizens in this respect". 65 Nonetheless, "Regulation 1/58 [does not] set out a specific Community law principle of equality between languages". 66 In case of conflict between one or more linguistic version, as happened in the Stauder 29/69 case, the Court has stated that there is not one version that prevails over the others, ${ }^{67}$ but any disagreement has to be solved in the light of the purpose of the act itself. However, these principles are only true for normative acts, not for individual decisions, which would only need to be translated into the language of its addressee. Therefore, a different linguistic version from the original one would be trusted only if it was published to inform possible "interested third parties". Furthermore, since 2001, Article 41.4 of the Charter has declared that "every person may write to the institutions of the Union in one of the languages of the Treaties and must have an answer in the same language". Consequently, this expectation of good administration does not bind offices or agencies. 68

\section{Multilingual issues in EU agencies' communication}

Currently, although the EU affirms its multilingual nature by recognising the equal value of all versions of the Treaties (Article 55 TEU), within the Treaties it is not possible to

\footnotetext{
62 In the drawing up of EFSA's scientific assessment, the participation of interested parties is still missing, even though the General Court recently seems to have suggested the possibility of an internal review under environmental law, such as the provision of Art 10 of Regulation 1367/2006, extending the spectrum of the "parties" allowed to participate (as set out in Regulation (EC) 1107/2009). See Case T-33/16, Testbiotech eV, ECLI: EU:T:2018:135, paras 38, 80 and 89.

63 Regulation (EEC) 1/58 determining the languages to be used by the European Economic Community, [1958], OJ 017, 0385-0386.

64 J Ziller, Diritto delle istituzioni e delle politiche dell'Unione europea (Bologna, il Mulino 2013) pp 212-19.

65 S van der Jeught, EU Language Law (Zutphen, Europa Law Publishing 2015) p 123.

66 Case T-120/99, Kik, [2001], ECR II-02235, para 58.

67 Case 29/69, Stauder [1969] ECR 00419; Case C-369/89, Piageme, [1991] ECR I-02971, para 17.

68 See, inter alia, J Ziller, "Multilingualism and Its Consequences on EU Law" in HJ Blanke, PC Villalón, T Klein and J Ziller (eds), Common European Legal Thinking (Berlin, Springer 2016) pp. 437-56.
} 
clearly identify a legal basis for the protection of multilingualism outside of the institutions. This gap appears more relevant regarding the various technical or scientific opinions of agencies or committees that some of the delegated and implementing acts of the EU Commission are based on. ${ }^{69}$ Indeed, "the rules governing the languages of [only] institutions shall $[\ldots]$ be determined by the Council, acting unanimously by means of regulations" (Article 342 TFEU). As already claimed, EFSA does not adopt binding decisions for the Commission, whose power of decision is more complex and goes beyond the acts of the agency, because this is a political matter. At the same time, the use of acts of soft law by the agency, which are not regulated by either primary or secondary law, ${ }^{70}$ is very common. In fact, regulation by soft law has not been codified, even though, indirectly, it does produce legal effects and consequences. ${ }^{71}$ These acts actually play an important role that could "come close to generating universal Member States compliance to relatively detailed Union norms". ${ }^{72}$ In addition, most soft law acts, which lead the works of agencies and committees, are only published into two or three languages, usually English, French and German. Soft law acts are very common, but it would be better if all acts were translated into every official EU language for effective and full comprehension, in line with the claim from the Communication Handbook for the EU Agencies that, since 2013, "good multilingual communication [has contributed] to [the] image and reputation [of the EU]" ${ }^{73}$ In this sense, it is noteworthy that the communication campaign that EFSA is carrying out on its website has been improving for some years, with many videos explaining the decision-making processes (understanding science) and the aspects of its internal structure (how EFSA works). ${ }^{74}$ They are also subtitled, in addition to English, in some two or three other official EU languages, such as French, German and Italian. ${ }^{75}$ Effective communication, in fact, becomes even more crucial during the communication of risk and, in particular, during the communication of what risk is socially acceptable for food safety, in the belief that "proactive communication"" can also increase public confidence in future research activities based on the assessment of these risks. ${ }^{77}$ On the one hand, a model using more

\footnotetext{
69 Case T-120/99, Kik, supra, note 66, para 64.

70 M Chamon, "Le recours à la soft law comme moyen d'éluder les obstacles constitutionnels au développement des agences de l'UE”' (2014) 576 Revue de l'Union Européenne 160.

71 JF Flauss and J Iliopoulos-Strangas (eds), Das soft law der europäischen Organisationen - The Soft Law of European Organisations - La soft law des organisations européennes (Baden-Baden, Nomos 2012); L Senden, Soft Law in European Community Law (Oxford, Hart Publishing 2004) p 112; L Senden and A van de Brick, Check and Balances of Soft Law EU Rule Making (2012) <www.europarl.europa.eu/RegData/etudes/etudes/join/2012/462433/ IPOL-JURI_ET(2012)462433_EN.pdf>.

72 M Shapiro, "Independent Agencies" in P Craig and G De Bùrca (eds), The Evolution of EU Law (Oxford, Oxford University Press 2011) pp 111-20, 115.

73 Communication Handbook for the EU Agencies, supra, note 59, p 10.

$74<$ www.efsa.europa.eu/it/topics/videos>.

75 Regarding some open issues related to explanatory videos and subtitles, see A Monica, "Regolazione e accountability del settore alimentare: come l'attività di comunicazione della conoscenza scientifica può aumentare la trasparenza e la partecipazione" in N Bassi and J Ziller (eds), La formazione procedimentale della conoscenza scientifica ufficiale: il caso dell'Agenzia europea per la sicurezza alimentare (EFSA), supra, note 1, 127.

76 ibid, 127.

77 On this point, see S Chakraborty, "The Role of Communication in Promoting a European Wide Approach to Risk Based Regulation" (2012) 1 European Journal of Risk Regulation 112; G Sturloni, La comunicazione del rischio per la salute e per l'ambiente (Milan, Mondadori 2018), pp 120-21.
} 
than one common language may be a problem because "it simply cannot guarantee communication between all EU citizens", ${ }^{78}$ but on the other hand, using only one language will lead to the supremacy of the English language as a vehicular language because it is the most popular and well-known language in the EU. ${ }^{79}$ In fact, neither Article 41 of the Charter nor Article 2 of Regulation 1/58 say anything concerning the bodies and offices using all of the languages of the EU institutions in opinions or working documents. Only general documents and regulations must be drafted in the official language. ${ }^{80}$ On the whole, this non-duty of translation is a barrier to some "possible interested third parties". In this sense, the practice of the use of English as the preferred working language contradicts the notion of the equal value and dignity of the 24 "official and working languages".

This is to say that, in view of broader multilingualism in the future, it will be of paramount importance not to lose the original meaning of concepts, as well as to improve public trust of the scientific regulatory process. ${ }^{81}$ The linguistic services of the EU institutions will be called upon in order to make a joint effort to overcome linguistic problems. Today, EFSA provides the possibility of structured participation, but only for stakeholders. They are classified into the following categories: consumers; environmental/health NGOs and advocacy groups; farmers and primary producers; business and food industries; distributors and organisations representing stakeholders involved in distributing and serving food; associations of practitioners; and academia. All of them are involved in predefined working groups and laboratories. It is also agreed that some observers should take part in plenary meetings; in this case, the decision to hold an open plenary meeting is taken by EFSA in agreement with either the Scientific Committee or the relevant Scientific Panel. The observers have to register before attending, stating the reason for their interest. For all of these reasons, a legitimate question might be: what legal protection is actually given to a "third party" who is part of an organised group ${ }^{82}$ but does not have a good command of the English language? Even though English is the most likely lingua franca, the comprehension of all lexical nuances and legal minutiae is largely related to an adequate command of the language. ${ }^{83}$

Principles, and especially such principles as the principle of multilingualism, which allows EU institutions and agencies to communicate, are guiding administrative

78 S van der Jeught, EU Language Law, supra, note 65, p 270.

79 ibid, 271. Even though, according to the opinion of the Commission ("Multilingualism: An Asset for Europe and a Shared Commitment", COM/2008/0566 final), multilingualism is a resource for citizens to strengthen integration among people, this lack of duty for the equal dignity for every linguistic version of preparatory works could also affect cooperation between Member States and EU bodies or offices.

80 Regulation 1/58 Arts 1 and 4.

81 Regarding the quality of drafting of Community legislation and legal terminology, see M Guggeis, "I giuristi linguisti e le sfide per garantire la concordanza, qualità redazionale e corretta terminologia giuridica nei testi normative dell'Unione europea" in Il linguaggio giuridico nell'Europa delle pluralità (Rome, Senato della Repubblica 2017), pp 49-66.

82 Regulation (EC) 726/2004 laying down Community procedures for the authorization and supervision of medicinal products for human and veterinary use and establishing a European Medicines Agency, [2004], OJ L 136, 1-33, Art 78, para 2.

83 S van der Jeught, EU Language Law, supra, note 65, p 273. At the same time, the Courts remind us that "As the appellant points out, the Treaty contains several references regarding the use of languages in the European Union. None the less, these references cannot be regarded as evidence of a general principle of Community law that confers a right on every citizen to have a version of anything that might affect his interests drawn up in his language in all circumstances", C-361/01 Kik c. UHMI, ECLI:EU:C:2003:434, para 82. 
activities. They are all necessary tools to define rules. There can be no doubt that the EU system is now integrated with the systems of the Member States not only from a legal perspective, but also from an administrative point of view. ${ }^{84}$ Since 2014 , the EU Ombudsman Emily O'Reilly, operating as a system fixer, ${ }^{85}$ has also focused her mandate on the importance of clear communication and the use of languages in processes ranging from trilogues to agency activities. ${ }^{86}$ "The principles governing [...] this language regime apply also to other forms of communication, such as communication through publications and websites. Any differentiation in the use of languages in such circumstances should be objectively justified". ${ }^{87}$ As previously explained, there is an important issue regarding reliable communication with the general public. Thus, the EU Ombudsman may try to suggest some solutions and agreements to the problem of multiple and non-corresponding versions of documents and acts. The EU Ombudsman, using their power of persuasion, may try to encourage the adoption of guidelines to help cope with problems of communication and translation. Up until now, there has not been a general European law on administrative procedure ${ }^{88}$ that could fill the gap of binding law regarding the multilingual principle and its implications for "third parties", but Article 8 of the Proposal for a Regulation of the European Parliament and of the Council for an Open, Efficient and Independent European Union Administration, among its procedural rights, suggests "[using] any of the languages of the Treaties and [being] addressed in the language of the Treaties of their choice". At the same time, "the Union's administration should ensure that its administrative acts are drafted in a clear, simple and understandable language" ${ }^{89}$ Effective freedom of language throughout the EU has to be possible for citizens, and in this sense, the absence of restriction in the language policy may directly impact the legitimacy of EU bodies as well. ${ }^{90}$ This matches the purpose that outcomes must also resonate with citizens' substantive values and principles in order to be perceived as acceptable and appropriate and not just as matching citizens' (technically established) interests. ${ }^{91}$

\footnotetext{
84 E Chiti and C Franchini, L'integrazione amministrativa europea (Bologna, il Mulino 2003) p 91; P Craig, $U K, E U$ and Global Administrative Law (Cambridge, Cambridge University Press 2015) pp 314-15.

$85<$ https://eur-lex.europa.eu/summary/glossary/ombudsman.html>.

86 European Ombudsman, Case 1206/2016/PL on the failure by the Commission to answer correspondence in the language of the complainant; Case OI/8/2015/JAS Letter to the Council of the EU opening the European Ombudsman's own-initiative inquiry OI/8/2015/FOR concerning transparency of trilogues; Case 946/2014/PL on the use of languages on its website and publications, in particular about the discriminatory language policy of Fundamental Right Agency (FRA).

87 European Ombudsman, Decision in case 478/2014/PMC concerning the European Commission's bilingual visual identity used in its press conference room.

88 H Hofmann, JP Schneider and J Ziller, "The Research Network on European Administrative Law's Project on EU Administrative Procedure - Its Concepts, Approaches and Results" (2014) 7 Review of European Administrative Law 45; and, more recently, D-U Galetta, H Hofmann, O Mir and J Ziller, The General Principle of EU Administrative Procedural Law, June 2015 <www.europarl.europa.eu/RegData/etudes/IDAN/2015/519224/IPOL_IDA(2015)519224_EN.pdf>.

89 European Parliament, Proposal for a Regulation of the European Parliament and of the Council for an Open, Efficient and Independent European Union Administration, supra, note 55, recital 33.

90 S van der Jeught, EU Language Law, supra, note 65, pp 240, 266.

91 VA Schmidt, "The Eurozone's Crisis of Democratic Legitimacy: Can the EU Rebuild Public Trust and Support for European Economic Integration?" EU Press, $2015<$ https://ec.europa.eu/info/sites/info/files/dp015_en.pdf>. The author speaks of a "'Weberian' legitimacy [...] involving not only cognitive arguments that translate the technical assessments into language accessible to the general public but also normative ones that seek to show how the policies resonate with societal values - whether long-standing or newly-emerging", p 12.
} 


\section{Conclusion}

A common thread to all of the reasoning above is the reliability of the EU agencies' technical assessments in the case of food safety opinions. The Xylella case has shown that it is difficult for some "third parties", such as olive farmers, to understand the decisional process referring to the Implementing Decision that impacts them directly. Even though this fact is also strictly related to the public understanding of science, ${ }^{92}$ from the a procedural perspective, a better protection of "third parties" in EU administrative procedures, such as decisions relying on EFSA opinions, may be possible, assuring, for instance, their rights to be informed. In order to guarantee the fairness of administration, ${ }^{93}$ technical agencies such as EFSA operate on the basis of the principle of independence and transparency and on the trust in the quality of the assessments it carries out. Therefore, this process is strictly related to the development and diffusion of the preliminary technical assessment material of the final regulation. In this sense, according to the principle of multilingualism, enhancing all aspects of the communication of rulemaking or of individual decisions allows for a better understanding of the administrative system and of the decisions based on the precautionary principle, applied both where the extent of a risk is uncertain and where there is doubt as to its very existence. ${ }^{94}$ For this reason, the communication of activities may not be self-referential, but there must be coordination among the EU institutions, agencies and offices, as well as with other actors involved.

It is always necessary to find a compromise between consumer interests or the pluralistic interests of knowledge with the specific economic interests involved. The Xylella case is a good example of this dichotomy because of the negative and uncontrolled consequences of incorrect and incomplete communication, which could be misrepresented by "other possible interested parties" and also by public opinion. At the Italian national level, there is still an ongoing counter-information campaign suggesting that infected plants should not be felled, but treated. ${ }^{95}$ Unchecked communication, just like the lack of knowledge of the real role played by Member States in the execution of an Implementing Decision, has highlighted the necessity of developing more coherent and more confident information dissemination. ${ }^{96}$ If it is true that in highly technical areas such as the food market the involvement of scientists and experts is necessary and serves to "reassure the public", 97 at the same

\footnotetext{
92 According to the issue of the speed of political decision-making being faster than the speed of scientific consensus formation and the spreading distrust towards science, inter alia, M Michael, "Ignoring Science: Discourses of Ignorance in the Public Understanding of Science" in IA Irwin and B Wynne (eds), Misunderstanding Science? The Public Reconstruction of Science and Technology (Cambridge, Cambridge University Press 1996), pp 107-25; HM Collins and R Evans, "The Third Wave of Science Studies: Studies of Expertise and Experience" (2000) 32 Social Studies of Science 235.

93 See Commission White paper on European governance openness and accountability (COM 2001/428 final).

94 Case T-74/00 Artegodan GmBh, [2002] II-04945, paras 184-86.

95 EFSA, "Response to Scientific and Technical Information Provided by an NGO on Xylella fastidiosa", supra, note 31, and C-443/18, Commission v. Italia, supra, notes 40-42.

96 Regarding the need for "correct communication" in EU administration, see G Vilella, Working Methods of the European Parliament Administration in Multi-Actors World (European Press Academic Publishing 2019).

97 M Everson, "Independent Agency: Hierarchy Beaters?" (1995) 1 European Law Journal 191.
} 
time the independence and the reliability of expertise (upon which the scientific opinions of EU agencies are based) have to be trusted. Indeed, taking into account the reasons why a "third party" would make the management of risk accountable also implies the possibility of making the process of scientific assessment more trustworthy. A good approach would be the translation of assessments in full into all 24 EU languages, but this is expensive, of course, in terms of both time and money. For the time being, agencies have to cope with the restraint of EU budgetary limits that force them to make choices according to their expenditure, including for full translations. ${ }^{98}$ In any case, as a first step, it will be possible to be supported by existing legal databases or corpora, thereby improving their functionality. ${ }^{99}$ For the moment, in order to overcome the still open problem of multilingualism outside of the institutions, a coherent process of disseminating information, such as explanatory videos, could boost the EU's reputation as a "quality administration". This fact would help to make the EU's official scientific knowledge process "participative" 100 and more coherently organised, and therefore more "accountable". ${ }^{101}$ Accountability is "a good thing of which it seems we cannot have enough", ${ }^{102}$ or better, as for the majority of legal scholarship, it is the attempt of the actor who has made a decision to explain and justify their conduct in a forum and face the possible consequences. ${ }^{103}$ Furthermore, if the reputation of the EU's technical agencies was significantly boosted, their political legitimacy itself would increase. ${ }^{104}$ In this sense, a clear and understandable language that tries to go beyond the issues related to multilingualism and noncorresponding linguistic versions of a document ${ }^{105}$ is also a vehicle of legitimation of any risk assessment in a democratic process.

\footnotetext{
98 For an example of a recent attempt by the Commission to cope with multilingual issues, but within the constraints of budgetary limits, see Regulation 2018/1724/EU, establishing a Single Digital Gateway [2018]OJ L 295, at Art 32, c. 1, lett. C).

99 For example, Interactive Terminology for Europe (IATE) <www.iate.europa.eu>. See, inter alia, M Barbera, E Corino and C Onesti, "Linguistica giuridica italiana on line. Dalle banche dati alla linguistica dei corpora" in $I l$ linguaggio giuridico nell'Europa delle pluralità (Rome, Senato della Repubblica 2017), pp 123-50.

100 A similar conclusion is also the concept of "consensum communication" based on comparing the parties involved: G Sturloni, La comunicazione del rischio per la salute e l'ambiente, supra, note 77, pp 106-12.

101 Chiti understands accountability as a set of regimes "that is as components of sets of principles rules and process coherently organised”, E Chiti, Is EU Administrative Law Failing in Some of Its Crucial Tasks?, supra, note 55.

102 M Lodge and M Busuioc, The Reputational Basis of Public Accountability (2016) 29 Governance 248.

103 M Bovens, "Analysing and Assessing Public Accountability: A Conceptual Framework" (2007) 4 European Law Journal 452.

104 C Harlow, "Editorial: Transparency, Accountability and the Privileges of Power" (2016) 22 European Law Journal 273.

105 Supra, note 75.
} 